Article

\title{
The Centrality of Anti-Semitism in the Islamic State's Ideology and Its Connection to Anti-Shiism
}

\author{
Daniel Rickenbacher ${ }^{1,2}$ \\ 1 Concordia Institute for Canadian Jewish Studies, Montreal, QC H3G 1M8, Canada; \\ daniel.rickenbacher@concordia.ca \\ 2 Canadian Institute for Jewish Research, Montreal, QC H3G 2K7, Canada; daniel.rickenbacher@cijr.com
}

Received: 14 June 2019; Accepted: 7 August 2019; Published: 16 August 2019

\begin{abstract}
The Islamic State (ISIS) has repeatedly targeted Jews in terrorist attacks and incited against Jews in its propaganda. Anti-Semitism and the belief that Jews are engaged in a war against Islam has been central to Islamist thought since its inception. Islamist anti-Semitism exposes the influence of both Western conspiracy theories and Islamic traditions. This article studies the anti-Semitic themes propagated by ISIS and investigates their ideological foundations. It bases itself on an analysis of articles published in Dabiq, ISIS' English language online magazine in the period 2014-2016. This study shows that ISIS' relationship with Western-inspired anti-Semitic conspiracy theories is inconsistent, vacillating between rejection and acceptance. ISIS holds an apocalyptic, anti-Semitic worldview, which claims that the Shia denomination is a Jewish invention to sow disunity among Muslims and that Shia and Jews are working together to destroy Islam. ISIS' anti-Semitism and anti-Shiism are thus inherently connected. It is vital to correctly assess the anti-Semitic ideological foundations of contemporary Islamism and Jihadism to best understand the movement. Learning about this will help lawmakers, scholars and practitioners develop strategies to deal with these movements and counter their message.
\end{abstract}

Keywords: Islamic State; ISIS; anti-Semitism; anti-Shiism; Islamism; terrorism; genocide; radicalization

\section{Introduction}

Since 2014, Islamic State (ISIS) terrorists and sympathizers, who pledged allegiance to the group, have repeatedly targeted Jews in Western countries. In May 2014, an ISIS foreign terrorist fighter stormed a Jewish Museum in Brussels, murdering four individuals. In January 2015, an ISIS sympathizer took several people hostage at a kosher supermarket in Paris, murdering four others. One month later, an ISIS sympathizer shot at a free speech event and later at a synagogue, murdering two, including the synagogue's security guard (Ellis 2015). On 13 November 2015, ISIS terrorists murdered 130 people in several attacks. Most victims were killed in the Bataclan theatre. Due to its former Jewish, pro-Israeli owners, anti-Israeli and Islamist groups repeatedly planned on attacking the theatre (Le Point 2015). In March 2016 in Brussels, ISIS attacks killed 32 people; one suicide bomber specifically targeted two Orthodox Jews at the airport, who were both injured in the attack (Carmichael 2017). There were also several lower-profile attacks on Jews. In January 2016, for instance, an ISIS sympathizer tried to decapitate a kippah-wearing Jewish man in Marseille (Haguesher 2017). Security services prevented many other terrorist attacks.

In the US, ISIS sympathizers repeatedly plotted attacks on Jewish communities (Barsky 2016, pp. 72-73). In December 2018, police arrested an ISIS sympathizer for planning an attack on a synagogue in Toledo, Ohio. His immediate inspiration was the October 27 attack on a Pittsburgh synagogue, where a white supremacist murdered eleven congregants. The prospective terrorist told an 
FBI undercover agent: "I admire what the guy did with the shooting actually. [...] I can see myself carrying out this type of operation inshallah" (Department of Justice U.S. Attorney's Office Northern District of Ohio 2018). What was the rationale behind these actions? For years, ISIS cultivated hatred of Jews and other non-Muslims in its propaganda outlets. Its videos, articles, and songs are a source of fantasies for violence, which inspire its followers globally. In this vein, ISIS repeatedly calls for the murder of Jews, such as it did in 2015: "Stab the Jew with a knife or run over him with a car, poison him, bring back explosives, [... make use of] explosive belts and IEDs, burn their faces and their houses" (The Meir Amit Intelligence and Terrorism Information Center 2015, p. 2).

ISIS' acts of religious violence defy standard definitions of terrorism, which tend to see terrorism as the rational use of violence to achieve a political goal. ${ }^{1}$ However, many have noticed that Islamist terrorism, especially after 9/11, did not fit these traditional definitions. Terrorism was no longer primarily a strategic tool to advance political interests, as it had been during earlier terrorist waves (Rapoport 2004). Jihadi groups like Al-Qaeda see their actions as a sacred duty and deny the humanity of their enemies. Killing civilians—as many and as gruesomely as possible-became a goal in itself. As the Canadian political scientist Barry Copper succinctly put it back in 2005: "The chief practical consequences of taking part in a cosmic struggle with a satanic enemy is that the enemy must be extinguished" (Cooper 2005, p. 57). Since 9/11, terrorism became deadlier, as different Islamist terrorist groups competed for the highest death toll. ISIS can be considered a culmination of this development of sacralization of violence.

Because they prioritize ritual over strategic violence, Jihadi terrorist groups have proven ineffective in reaching political goals. Both Al-Qaeda and the Islamic State miscalculated the consequences of their actions, resulting in the destruction of the Al-Qaeda safe haven in Afghanistan and the Islamic State in Iraq/Syria.

These observations do not imply that Jihadi groups are irrational, but that the rationale of their actions can only be studied and understood within the framework of their ideology. The indiscriminate targeting of Westerners, Jews, and non-Sunni-Muslims can be rationalized by the belief that they are part of a global war to destroy Islam, which Islamists and Jihadists tend to maintain (Rickenbacher 2019). Terrorizing these groups then serves the purpose of undermining their morale and deterring them from continuing their war against Islam. ${ }^{2}$ Even extreme violence can seem justified to some under these circumstances.

ISIS is, in fact, genocidal in its ambitions, as it makes repeatedly clear both in words and actions. Thus, ISIS warned that if it was to conquer Europe, it would perpetrate a genocide against the Jews overshadowing the horrors of the Holocaust: "The clear difference between Muslims and the corrupt and deviant Jews and Christians is that Muslims are not ashamed of abiding by the rules sent down from their Lord regarding war and enforcement of divine law. [...] As for the treacherous Jews of Europe and elsewhere- - those who would betray their covenant- then their post-pubescent males would face a slaughter that would make the Holocaust sound like a bedtime story, as their women would be made to serve their husbands' and fathers' killers" (Islamic State and Al-Hayat Media Center 2016a, p. 80). These are not empty words. When ISIS had the chance, it perpetrated genocide against the Yazidi. It also continues to perpetrate mass slaughter against Christians and the Shia.

This article seeks to understand the ideological foundations of this hatred based on an analysis of articles published in Dabiq, an English language online magazine that ISIS edited between July 2014 and July 2016. Its articles covered ISIS' theological and political reflections and dealt with important

1 Probably the most quoted definition of terrorism was written by Bruce Hoffman: "We may therefore now attempt to define terrorism as the deliberate creation and exploitation of fear through violence or the threat of violence in the pursuit of political change. All terrorist acts involve violence or the threat of violence. Terrorism is specifically designed to have far-reaching psychological effects beyond the immediate victim(s) or object of the terrorist attack. It is meant to instill fear within, and thereby intimidate, a wider 'target audience' [...]." (Hoffman 2006, pp. 40-41).

2 Thanks to the anonymous reviewer for underlining this element of rationality in Jihadist violence. 
events in the history of the Islamic State. Its primary function was to provide religious justifications for ISIS' actions (Gambhir 2014, p. 2). Dabiq articles afford insight into ISIS thought and self-presentation vis-à-vis its followers and the larger world, providing an excellent sample to study ISIS' justifications for religious hatred and violence. Notwithstanding the destruction of its caliphate, ISIS and its ideology are likely to endure, which makes it all the more important to understand its belief system.

\section{ISIS' Ambivalence toward the 'Jewish-Western War Against Islam' Conspiracy Theory}

Jews occupy a special place in Islamist thought. Islamists believe in a worldwide Jewish-Western conspiracy to destroy Islam. In the process of formulating this theory, Islamist movements extensively adopted anti-Semitic European conspiracy theories. Sayyid Qutb, one proponent of the theory, claimed in his pamphlet 'Our Struggle with the Jews [Arab. "Ma'rakatuna ma 'a al-Yahud"] that the Jews had been involved in a cosmic war to destroy Islam since its founding (Tibi 2010, pp. 11-14). That Qutb challenged Islam's discriminatory but protected status assigned to the Jews as a people of the book [Arab. "Ahl al-kitāb"] is a testament to the depth of Qutb's anti-Semitism. The Hamas Charter famously quotes the Protocols of the Elders of Zion directly. Abdallah Azzam, the founder of Al-Qaeda, was another believer. He created the terrorist group to counter this global war by the "Crusader-Jewish alliance"(Rickenbacher 2019, pp. 166-67). This adoption of European anti-Semitic thought compromises the Islamist claim that their movement presents a return to the sources of Islam. Political expediency trumped ideological purity.

European conspiracy theories were not the only source for the belief in a global Jewish-Christian war to destroy Islam. Traditional Islamic views envisage a perpetual war, jihad, between Islam and the non-Muslim 'world of war' [Arab. "Dar al-Harb"] until the latter is converted to Islam. According to Islamic law, it is a collective duty [Arab. "Fard al-Kifayah"], meaning a legal obligation, to wage this offensive religious war. In the case of a defensive war, however, Islamic law stipulates that religious war becomes an individual duty [Arab. "Fard al-Ayn"] for every Muslim. In both instances, religious war is administered by an Islamic state, whatever its current political expression (Lewis 1991). Historically, Islamic states were usually reluctant to fight a perpetual war. During the reform period, the Ottoman Empire, the last of the great Islamic empires, increasingly prioritized state interests, only to relapse into religious war in WWI; the young Turks explicitly saw their campaign of extermination against non-Muslim minorities as a jihad, foreshadowing the genocide perpetrated by the Islamic State one hundred years later (Kieser 2018, p. XIV). The secular states, which succeeded the Ottoman Empire, abandoned the 'duty' to wage religious war entirely-much to the chagrin of the pan-Islamic, and later the Islamist movement. Violent Islamist or Jihadists, such as Abdallah Azzam, justified their call for individual jihad, by claiming that they are defending the Islamic world from a war of aggression, especially since there are no states to take on this duty. ${ }^{3}$

Islamic eschatology, in addition to Western conspiracy thought and the traditional Islamic political conception of continued warfare with the non-Muslim world, is another important source for the contemporary 'War against Islam' narrative. It is also the most important influence on ISIS' anti-Semitism, as I will discuss in the next section. Still, ISIS' relationship with the 'War against Islam' conspiracy theory and conspiracy theories in general, is ambivalent. Many ISIS statements promulgate this theory. On the other hand, there are also dissenting voices. Thus, the author of the remarkable Dabiq article 'Conspiracy Theory Shirk' methodologically criticizes the widespread belief in a century-old, global conspiracy against Islam orchestrated by its enemies. He argues that such ideas are un-Islamic and entered the Islamic movement through Arab nationalism (Islamic State and Al-Hayat Media Center 2015a, p. 15). Since the belief in the 'War against Islam' is so fundamental to Islamism and feeds much of its anti-Semitism, it is worth taking a closer look at the article and its arguments.

3 On the evolution of individual jihad in Islamist thought, see (McGregor 2003; Hegghammer 2010). 


\section{Is Conspiracy Theory Shirk?}

The author of the article enumerates several reasons why Muslims must reject conspiracy theories. He argues that they serve the enemies of Islam: "The purpose of conspiracy theories is to exaggerate the power of the kuffār [non-Muslims], and thereby the Muslims become paralyzed by analysis of current events and eventually fear the kuffār more than they fear Allah" (Islamic State and Al-Hayat Media Center 2015a, p. 19). Furthermore, he argues that while non-Muslims, indeed, conspire against Islam, these actions are usually unsuccessful, since the non-Muslims are disunited and their alliances unstable: "The kuffār are divided, hold animosity and enmity towards each other, carry out violence against each other, humiliate and degrade each other, yet they unite against the Muslims, their common enemy. [...] The kuffār undoubtedly do plot out conspiracies, but these plots are weak due to the fragile relationships the kuffār have with each other" (Islamic State and Al-Hayat Media Center 2015a, p. 18). In the view of the author, conflicts between non-Muslims are real. He, therefore, ridicules those "believing that the Christians, Răfidah [Shia], Jews, and apostates are all covert members of the same secret society, underground political party, or grandiose conspiracy theory, all of them adoring each other and faking their hostilities" (Islamic State and Al-Hayat Media Center 2015a, p. 19).

Worst of all, conspiracy theories attribute god-like capabilities to the human enemies of Islam, which effectively amounts to shirk, meaning idolatry, an offense punishable by death: "They do not see all, hear all, know all, control all, and own all, as some individuals try to portray them. Whoever believes that has fallen into shirk" (Islamic State and Al-Hayat Media Center 2015a, p. 18). The only being able to organize these sorts of elaborate conspiracies is Allah, who is fighting on the side of Muslims against the non-Muslims: "Rather, they [the non-Muslims] are the object of Allah's plot against them. [...] Grand conspiracies consist of so many factors only controllable by Allah (ta'ālā). An example of such a grand conspiracy theory is that of September 11th being carried out by the Americans themselves. How many members of the crusader government would have to be under permanent watch to prevent news of the operation getting out before its execution?" (Islamic State and Al-Hayat Media Center 2015a, p. 18) Moreover, the author argues that since the enemies of Islam are humans and lack the support of Allah, they cannot keep their conspiracies hidden: "Their real conspiracies always have material evidence and are not based on unsupported deductions-(guessing at the unseen). [...] The real conspiracies were not secrets hidden from mankind. The Iraqi Sahwah openly met with Bush, the Iraqi regime, and Rāfidī leaders" (Islamic State and Al-Hayat Media Center 2015a, p. 18).

Interestingly, the article also casts doubt on the belief that Jews are the leaders of the conspiracy of Islam since their status is inferior to both the Muslims and Christians: "This verse explains that the accursed Jews are always in humiliation and overpowered. The Jewish state itself was established for the Jews primarily by the British crusaders. It was through Jewish-crusader relationships and the self-degradation of the Arab apostates that the Jews gained mastery over the Arab tawāghit [secular Arab regimes]" (Islamic State and Al-Hayat Media Center 2015a, p. 18). It would, however, be wrong to conclude that ISIS rejects anti-Semitic conspiracy theories. Their rejection of some conspiracy theories is a function of their agenda to push back against any influences from the Western world.

On the contrary, ISIS statements have repeatedly affirmed the existence of Jewish led 'War against Islam.' In September 2014, for instance, ISIS spokesman Mohammad al-Adnani blamed the Jews for the military intervention against the Islamic State. At the proclamation's start, he quoted Sura 8:30, which discussed plans made by Mohammed's opponents in Mecca (Al-Adnani 2014). These statements were meant to underscore the conspiratorial, anti-Islamic nature of the non-Muslims, as well as the continuity of the 'War against Islam' from the time of the founding of Islam until today. In Dabiq's first issue, Abu Bakr al-Baghdadi proclaimed that "the world today has been divided into two camps and two trenches, with no third camp present: The camp of Islam and faith, and the camp of kufr (disbelief) and hypocrisy - the camp of the Muslims and the mujahidin everywhere, and the camp of the Jews, the crusaders, their allies, and with them the rest of the nations and religions of kufr, all being led by 
America and Russia, and being mobilized by the Jews" (Islamic State and Al-Hayat Media Center 2014a, p. 10).

Moreover, some of the ISIS' statements against Jews and Israel are of secular origin; they reflect classical anti-Zionist and Arab nationalist arguments. Thus, in issue four of Dabiq, the author writes that "It seems American leaders are blinded by their love of the Jewish state into doing things that only damage supposed Western interests" (Islamic State and Al-Hayat Media Center 2014b, p. 40). Another Dabiq article uses Arab nationalist language to attack Zionism: "Zionism feeds this conspiracy to extract Palestine from the body of the Arab nation for whom Palestine is its throbbing heart" (Islamic State and Al-Hayat Media Center 2016b, p. 32). Former US president Barack Obama is also repeatedly graphically portrayed as being close to Israel and the Jews. One picture in Dabiq shows him praying with a kippa at the Western Wall (Islamic State and Al-Hayat Media Center 2014c, p. 36). In another photo he is speaking in front of US and Israeli flags (Islamic State and Al-Hayat Media Center 2014b, p. 40). These pictures seek to insinuate that Israel and the Jews are in control of the US.

For ISIS, just as for other Islamists, the Jews remain the primary enemies of Islam, even though ISIS outwardly, but inconsistently, rejects the influence of Western conspiracy thought on Islamism. As will be discussed in the next section, ISIS' main reference point for its own 'War against Islam' narrative is Islamic eschatology.

\section{The Role of Israel in ISIS' Thought}

There are numerous indications that ISIS sees itself as living at the end of times; even the title of the magazine-Dabiq—clearly indicates this. According to Islamic eschatology, the final battle between Muslims and their enemies will take place in the Syrian city of Dabiq (Gambhir 2014, pp. 2-3). Apocalyptic thought is widespread among Islamists, who interpret many events of contemporary history as indications of an impending apocalyptic age. Century cycles repeatedly inspired millennial movements, which sought to restore the glory of Islam (Wessinger 2016, p. 277). The century cycle of 1979, the Islamic year 1400, saw the Islamic revolution in Iran, the Islamist attack on the Great Mosque in Mecca, and the Soviet invasion in Afghanistan. This chain of events fired up apocalyptic visions that were massively circulated in the 1980s through audio recordings and pamphlets (Landes 2011).

Several hadiths can be interpreted as prophesizing a global 'War against Islam' during the Last Days (Cook 2005, p. 137). Therefore, the belief in the existence of a 'War against Islam' and the sense that one lives in an apocalyptic age are connected and mutually invigorating. Moreover, anti-Semitism plays a prominent role in contemporary apocalyptic literature. The anti-Jewish elements of Islamic apocalyptic thought are no recent innovations: Classical Islamic literature already describes the Dajjal, the Muslim counterpart to the Antichrist, as Jewish. Contemporary apocalyptic literature emphasizes the anti-Semitic nature of the Dajjal narrative: They see the Dajjal and his Jewish followers as leaders of the Jewish conspiracy against Islam (Cook 2016). The above is the narrative which ISIS endorses.

The land of Israel and Jerusalem are central to Islamic apocalyptic thought-as well as to ISIS. According to Islamic eschatology, the Muslims will take refuge from the Antichrist, the Dajjal and his allies, the Jews in the land of Israel. Here Jesus will eventually reappear and defeat the Antichrist, the Dajjal, in a final battle. For these events to take place, the Muslims first must take control of the holy land (Cook 2008, p. 22). ISIS repeatedly makes clear that it subscribes to this apocalyptic vision. In December 2015, Abu Bakr al-Baghdadi released a statement, declaring that "We are getting closer to you day by day. [...] Do not think that we have forgotten about you. [...] It is the obligation of every Muslim to carry out Jihad. [... ] Jews, you will not enjoy in Palestine. God has gathered you in Palestine so that the Mujahadeen can reach you soon and you will hide by the rock and the tree. Palestine will be your graveyard" (Okbi and Hashavua 2015).

In his statement, Baghdadi alluded to the Gharkad hadith, which is also regularly quoted in Dabiq as well as in article seven of the Hamas Charter (Islamic State and Al-Hayat Media Center 2014d, p. 30). The hadith describes the massacre of the Jews that will take place in the Last Days according to Islamic eschatology: "The Day of Judgement will not come about until Moslems fight the Jews when the Jew 
will hide behind stones and trees. The stones and trees will say O Moslems, $\mathrm{O}$ Abdulla, there is a Jew behind me, come and kill him. Only the Gharkad tree, would not do that because it is one of the trees of the Jews" (Hamas 1988). Moreover, ISIS promises its followers the realization of these prophesies. In 2014, ISIS warned that "it is only a matter of time and patience before it reaches Palestine to fight the barbaric Jews and kill those of them hiding behind the Gharkad trees-the trees of the Jews" (Islamic State and Al-Hayat Media Center 2014e, p. 4). The mentioned time frame ("only a matter of time") underscores the fact that ISIS sees the Last Days as imminent and, therefore, considers it imperative to attack Israel.

ISIS and its predecessor organizations have tried to attack Israeli targets several times. Abu Musab al-Zarqawi's Jamaat al-Tawhid wa-l-Jihad planned such attacks in Germany in the early 2000 s. Moreover, some groups affiliated with ISIS in Gaza shot rockets at Israel, and in one firefight in the Golan, Israel killed several fighters of a group closely connected to ISIS (Wyss 2019). Still, other Islamist groups often criticize ISIS for its limited actions against Israel, spreading anti-Semitic conspiracy theories suggesting that ISIS is allied to Israel or even a covert Israeli operation. In an apparent effort to tackle this criticism, ISIS made statements that seem to accommodate Palestinian nationalism, as mentioned above. On the other hand, it also countered this criticism by arguing that the Islamic world's focus on the Palestinian issue is a legacy of secular Arab nationalism, and therefore must be rejected. Instead, Jihadi groups should focus their efforts on the 'Near Enemy,' meaning the secular Arab regimes in their countries (MEMRI 2019). Given the importance of anti-Semitic eschatological thought in its mindset, ISIS' limited actions against Israel and its denunciations of Arab nationalism do not mean that Israel does not preoccupy ISIS. Instead, the group will continue seeking to attack Israel, either directly or through its affiliates in Egypt and Gaza.

\section{The Connection between Anti-Shiism and Anti-Semitism}

A virulent anti-Shiism embodies the Islamic State's ideology. Invectives against the Shia, whom ISIS considers to be unbelievers and rejecters of Islam [Arab. "Rāfidah"], fill the pages of Dabiq. ISIS directs much of its violence against Shiites. In one of the worst war crimes perpetrated by the ISIS caliphate at Camp Speicher in Iraq in mid-June 2014, Shia soldiers were separated from their Sunni comrades and then executed. The massacre's death toll was estimated to be between 1500 and 1600 people (McKay 2017). Despite the enmity between Iran and Israel, ISIS believes that the Jews and Shias are allies: "And likewise, if the Jews establish a state in Iraq or elsewhere, the Rāfidah would be from their greatest supporters, because they always support the kuffār from the mushrikinn [Engl. "idolators"], the Jews, and the Christians. They help them in fighting and waging war against the Muslims" (Islamic State and Al-Hayat Media Center 2016c, p. 44). As we will see, ISIS' anti-Shiism is, in fact, closely connected to its anti-Semitism.

ISIS inherited its anti-Shiism from al-Zarqawi, the leader of Jamaat al-Tawhid wa-l-Jihad, which later became Al-Qaeda in Iraq and eventually renamed itself ISIS. During the US occupation of Iraq, al-Zarqawi sought to trigger a civil war by targeting the Shia. This policy was controversial within Al-Qaeda and was, to some extent, at odds with the organization's policies: Osama Bin Laden was inspired by the Islamic Revolution in Iran, and Al-Qaeda repeatedly worked with Iran and its proxy, Hezbollah (National Commission on Terrorist Attacks Upon the United States 2004, pp. 240-41).

Zarqawi had to defend his anti-Shia actions in Iraq vis-à-vis Al-Qaeda's leadership. In a letter to al-Zawahiri written in 2005, he accused the Shia of having always worked with the enemies of Islam and of presenting a danger to its existence: "People of discernment and knowledge among Muslims know the extent of danger to Islam of the Twelve'er school of Shiism. It is a religious school based on excess and falsehood whose function is to accuse the companions of Muhammad of heresy in a campaign against Islam, in order to free the way for a group of those who call for a dialogue in the name of the hidden Mahdi who is in control of existence and infallible in what he does. Their prior history in cooperating with the enemies of Islam is consistent with their current reality of connivance with 
the Crusaders." ${ }^{\prime 4}$ Zarqawi's statements reflected the widespread and increasingly popular anti-Shiism within Salafism.

This anti-Shiism, to a considerable extent, is an expression of Islamist anti-Semitism: It adopts elements from the 'War against Islam' narrative and anti-Semitic apocalyptic thought. ${ }^{5}$ Since the early 1990s, conspiracy theories gained popularity within Salafist circles accusing Shiites of working as agents of the Jews in their endeavor to destroy Islam. They hearken back to old Islamic legends, which claim that the Shiite denomination traces its roots back to Abdullah Ibn Saba, allegedly a Jewish convert to Islam (Mervin et al. 2013, pp. 42-44). Ibn Saba's portrayal as a Jewish deceiver is almost identical to and probably modeled after the Islamic perception of the Apostle Paul. In Islamic tradition, Apostle Paul is generally seen as having falsified the gospels and corrupted Christianity, distancing it from its monotheistic origins. There are two explanations in Islamic tradition for the Apostle Paul's motivations. One tradition sees him as an enemy of the Jews, while the other claims that Paul was a pseudo convert, a Jewish deceiver of the Christians (Kuhn 2018, p. 153). In the Islamist reading of these traditions, both Ibn Saba and Apostle Paul are adequately considered agents of the Jewish conspiracy against Islam, who set out to distort Christianity and Shiism and to drive a wedge between the Muslims, meaning the monotheists in this context. This Jewish conspiracy against monotheism-as evidenced by Apostle Paul's actions mentioned above-actually predates the founding of Islam.

Dabiq well represents this worldview. The story of the Jews' alleged corruption of Christianity and Islam is repeatedly told in its pages. In issue 13 of Dabiq, the featured article embraces this topic: "The Jews and the Răfidah are two sides of the same coin. The religion of Rafd ("Shiism") was nothing but a plot by a Jew-Ibn Saba' -following the footsteps of his Jewish predecessor Paul, who had corrupted the pure religion of the Messiah, leaving the Christians upon the Pauline deviance and heresies of the cross, original sin, incarnation, atonement, the lordship, divine sonhood, and godhead of the Messiah, and antinomianism (abandonment of the Law of Mūsā). [... ] The Jew Ibn Saba', like Paul, hated Islam and desired to deviate the Muslims and corrupt their religion by innovating deviant concepts including the godhood, lordship, and second coming of 'Alī Ibn Abī Tālib. At the same time, he strived to create strife amongst the Muslim ranks" (Islamic State and Al-Hayat Media Center 2016c, p. 33).

At the End of Days, Shias and Jews will reveal their true colors and unite to fight Islam, as described in several articles. According to Dabiq, "it is expected that the Răfidah will ally blatantly with the Jews in the future in their war against Islam and the Muslims" (Islamic State and Al-Hayat Media Center 2015c, p. 17). In ISIS' view, the Shia Mahdi, the final redeemer of the world, is identical with the Jewish Dajjal: "Their plan is to continue waging war against Islam until the emergence of the 'Mahdī' of the Rāfidah, who, according to them, will speak Hebrew, rule by the Torah, be followed by the Jews, and kill all the Arabs—attributes undoubtedly befitting the Jewish Dajjāl, not the Muslim Mahdī" (Islamic State and Al-Hayat Media Center 2015b, p. 52). "They will continue to wage war against the Muslims until the Rāfidah ultimately unite with the Jews under the banner of the Dajjāl. [... ] Finally, the Răfidah await the Jewish Dajjāl, who they plot to support alongside the Jews against the Muslim" (Islamic State and Al-Hayat Media Center 2016c, pp. 44-45). The fact that ISIS believes that the alliance between the Shia and the Jews is already happening in the present underscores that it believes itself to be living in an apocalyptic age.

\section{Conclusions}

Western anti-Semitic conspiracy theories profoundly influenced Islamist thought, challenging their claim that they represent a return to a pure form of Islam. ISIS, which tries to justify all its present

4 See for instance the anti-Shia passages in (Al-Zarqawi 2005).

5 As in the case of the forged Protocols of the Elders of Qom, a document claiming to reveal a secret Shiite plan to destroy Sunni Islam. Anti-Semitism is a clear inspiration, even though Jews are not even mentioned in the document. See Menahem Milson, (Milson 2011). 
actions through Islamic scripture, has recognized that a belief in such conspiracy theories is problematic from a religious fundamentalist point of view. Still, ISIS propaganda repeatedly promulgates classic anti-Semitic themes, such as Jewish control of the US. Moreover, ISIS' skepticism towards the influence of Western conspiracy theories on Islamism does not imply that ISIS is not steeped deeply in a conspiratorial worldview. Believing itself to live at the end of times, ISIS is primarily influenced by anti-Semitic eschatological thought, which has gained popularity in the Islamic World in the last three decades. It believes that both Christianity and in particular Shiism were created by Jewish deceivers. At the end of times, the Shia and the Jews will work together to destroy Islam.

Much like the political religions of the twentieth century, ISIS perverts the hierarchy of victim and perpetrator by presenting itself as engaged in a defensive war against the mortal enemies of Islam. This worldview serves as justification for ISIS' extreme violence against Jews, Shia, 'Crusaders,' meaning Christians, and other non-Muslims. The Global Terrorist Database counted more than 150 targeted attacks by ISIS against Christian and other religious sites since the group's inception until the end of 2017. On 21 April 2019, Easter Sunday, more than 250 people died in terrorist attacks on churches and hotels in Sri Lanka, for which ISIS claimed responsibility. The UN estimates that ISIS murdered about 5000 Yazidis in what amounts to the Yazidi Genocide. ISIS' genocidal actions and fantasies are a testament to the danger millennial Islamist movements present and to the need to counter them.

Funding: This research received no external funding.

Acknowledgments: I thank Jacques Chitayat for assisting me in the research for this article as well as Machla Abramovitz for proofreading the manuscript. I also thank the three anonymous reviewers for their helpful comments and suggestions.

Conflicts of Interest: The author declares no conflict of interest.

\section{References}

Al-Adnani, Abu Muhammad. 2014. A New Statement by IS Spokesman Abū Muhammad Al-'Adnānī Ash-Shāmī, September 22. Available online: http://triceratops.brynmawr.edu/dspace/bitstream/handle/10066/16495/ ADN20140922.pdf (accessed on 10 June 2019).

Al-Zarqawi, Abu Musab. 2005. Letter to Ayman Al-Zawahiri. Available online: http://triceratops.brynmawr.edu: 8080/dspace/handle/10066/4798 (accessed on 10 June 2019).

Barsky, Yehudit. 2016. Terrorist Incidents and Attacks Against Jews and Israelis in the United States. New York: Community Security Service.

Carmichael, Lachlan. 2017. Brussels Airport Bombers Targeted Jews, Americans, Investigators Say. Times of Israel, January 24. Available online: http://www.timesofisrael.com/brussels-airport-bombers-targeted-jewsamericans-investigators-say/ (accessed on 10 June 2019).

Cook, David. 2005. Understanding Jihad. Berkeley: University of California Press.

Cook, David. 2008. Contemporary Muslim Apocalyptic Literature. Syracuse: Syracuse University Press.

Cook, David. 2016. Anti-Semitic Themes in Muslim Apocalyptic and Jihadi Literature. Jerusalem: Jerusalem Center for Public Affairs, Available online: http://jcpa.org/article/anti-semitic-themes-in-muslim-apocalyptic-andjihadi-literature/ (accessed on 2 December 2016).

Cooper, Barry. 2005. New Political Religions, or an Analysis of Modern Terrorism. Columbia: University of Missouri Press.

Department of Justice U.S. Attorney's Office Northern District of Ohio. 2018. Ohio Man Arrested and Charged in Federal Court after Planning an Attack on a Synagogue in the Toledo Area. Cleveland: Department of Justice U.S. Attorney's Office Northern District of Ohio. Available online: https://www.justice.gov/usao-ndoh/pr/ohioman-arrested-and-charged-federal-court-after-planning-attack-synagogue-toledo-area (accessed on 10 June 2019).

Gambhir, Harleen K. 2014. Dabiq: The Strategic Messaging of the Islamic State. Washington, DC: Institute for the Study of War, Available online: http://www.understandingwar.org/sites/default/files/Dabiq\%20Backgrounder Harleen\%20Final.pdf (accessed on 10 June 2019). 
Haguesher, La rédaction d'. 2017. Sept ans de prison pour l'agresseur de Benjamin Amsellem. Haguesher, March 9. Available online: http://haguesher.com/2017/03/09/sept-ans-de-prison-pour-lagresseur-de-benjaminamsellem/ (accessed on 10 June 2019).

Hamas. 1988. The Covenant of the Islamic Resistance Movement (Hamas). Available online: https://avalon.law. yale.edu/20th_century/hamas.asp (accessed on 10 June 2019).

Hegghammer, Thomas. 2010. The Rise of Muslim Foreign Fighters: Islam and the Globalization of Jihad. International Security 35: 53-94. [CrossRef]

Hoffman, Bruce. 2006. Inside Terrorism. New York: Columbia University Press.

Islamic State and Al-Hayat Media Center, ed. 2014a. Foreword. Dabiq, July, pp. 3-4.

Islamic State and Al-Hayat Media Center, ed. 2014b. In the Words of the Enemy. Dabiq, September, pp. 35-36.

Islamic State and Al-Hayat Media Center, ed. 2014c. Khilafah Declared. Dabiq, July, pp. 6-11.

Islamic State and Al-Hayat Media Center, ed. 2014d. Reflections on the Final Crusade. Dabiq, October, pp. 32-44.

Islamic State and Al-Hayat Media Center, ed. 2014e. Remaining and Expanding. Dabiq, November, pp. 22-33.

Islamic State and Al-Hayat Media Center, ed. 2015a. Conspiracy Theory Shirk. Dabiq, May, pp. 14-19.

Islamic State and Al-Hayat Media Center, ed. 2015b. From the Battle of Al-Ahzab to the War of Coalitions. Dabiq, September, pp. 46-55.

Islamic State and Al-Hayat Media Center, ed. 2015c. The 'Mahdī' of the Rāfidah: The Dajjāl. Dabiq, September, pp. 16-17.

Islamic State and Al-Hayat Media Center, ed. 2016a. By the Sword. Dabiq, July, pp. 78-80.

Islamic State and Al-Hayat Media Center, ed. 2016b. The Murtadd Brotherhood. Dabiq, April, pp. 20-43.

Islamic State and Al-Hayat Media Center, ed. 2016c. The Rafidah from Ibn Saba' to the Dajjal. Dabiq, January, pp. 32-44.

Kieser, Hans-Lukas. 2018. Talaat Pasha: Father of Modern Turkey, Architect of Genocide. Princeton: Princeton University Press.

Kuhn, Michael F. 2018. Early Islamic Perspectives of the Apostle Paul as a Narrative Framework for Tahrif. In Arab Christians and the Qur'an from the Origins of Islam to the Medieval Period. Edited by Mark Beaumont. Leiden: BRILL.

Landes, Richard Allen. 2011. Heaven on Earth: The Varieties of the Millennial Experience, 1st ed. New York: Oxford Univ Press.

Le Point. 2015. Pourquoi le Bataclan est-il régulièrement visé? November 14. Available online: https: //www.lepoint.fr/societe/le-bataclan-une-cible-regulierement-visee-14-11-2015-1981544_23.php (accessed on 10 June 2019).

Lewis, Bernard. 1991. The Political Language of Islam. Chicago: University of Chicago Press.

McGregor, Andrew. 2003. 'Jihad and the Rifle Alone': 'Abdullah 'Azzam and the Islamist Revolution. Journal of Conflict Studies 23. Available online: https://journals.lib.unb.ca/index.php/JCS/article/view/219 (accessed on 10 June 2019).

McKay, Hollie. 2017. Grieving Iraqis Call on US to Investigate Massacre of 1600 Military Cadets. Fox News, June 22. Available online: https://www.foxnews.com/world/grieving-iraqis-call-on-us-to-investigate-massacreof-1600-military-cadets (accessed on 10 June 2019).

MEMRI. 2019. ISIS: Jihad in Palestine Does Not Take Precedence Over Jihad Elsewhere. Special Dispatch. Available online: https://www.memri.org/reports/isis-jihad-palestine-does-not-take-precedence-over-jihadelsewhere\#_edn3 (accessed on 12 June 2019).

Mervin, Sabrina, Rainer Brunner, Jean-François Legrain, Joseph Alagha, Reidar Visser, Thomas Pierret, and Roel Meijer. 2013. The Dynamics of Sunni-Shia Relationships: Doctrine, Transnationalism, Intellectuals and the Media. London: Hurst Publishers.

Milson, Menahem. 2011. A European Plot on the Arab Stage: The Protocols of the Elders of Zion in the Arab Media. Inquiry \& Analysis Series. MEMRI, May 20. Available online: https://www.memri.org/reports/ european-plot-arab-stage-protocols-elders-zion-arab-media (accessed on 10 June 2019).

National Commission on Terrorist Attacks Upon the United States. 2004. Final Report of the National Commission on Terrorist Attacks Upon the United States. Washington, DC: National Commission on Terrorist Attacks Upon the United States. 
Okbi, Yasser, and Maariv Hashavua. 2015. ISIS Leader Baghdadi to Jews: Palestine Will Be Your Graveyard. Jerusalem Post, December 26. Available online: https://www.jpost.com/Arab-Israeli-Conflict/ISIS-leaderBaghdadi-to-Israel-We-havent-forgotten-about-you-438483 (accessed on 10 June 2019).

Ellis, Ralph. 2015. Denmark Suspect Swore Fidelity to ISIS Leader. CNN, February 23. Available online: https://www.cnn.com/2015/02/16/europe/denmark-shootings/index.html (accessed on 10 June 2019).

Rapoport, David C. 2004. The Four Waves of Modern Terrorism. In Attacking Terrorism: Elements of a Grand Strategy. Edited by Audrey Kurth Cronin and James M. Ludes. Washington, DC: Georgetown University Press, pp. 46-73.

Rickenbacher, Daniel. 2019. Der jüdisch-westliche "Krieg gegen den Islam"-Genealogie und Aktualität einer islamistischen Verschwörungstheorie. In Antisemitismus im 21. Jahrhundert, Virulenz einer alten Feindschaft in Zeiten von Islamismus und Terror. Edited by Marc Grimm and Bodo Kahmann. Berlin and Boston: De Gruyter Oldenbourg.

The Meir Amit Intelligence and Terrorism Information Center. 2015. ISIS Campaign Inciting the Murder of Jews Inspired by Palestinian Wave of Terrorism. The Meir Amit Intelligence and Terrorism Information Center: Available online: https://www.terrorism-info.org.il/Data/articles/Art_20891/E_185_15_511090063.pdf (accessed on 10 June 2019).

Tibi, Bassam. 2010. From Sayyid Qutb to Hamas: The Middle East Conflict and the Islamization of Antisemitism. In Working Paper Series no. 5. Yale: Yale Initiative for the Interdisciplinary Study of Antisemitism.

Wessinger, Catherine. 2016. The Oxford Handbook of Millennialism. Oxford: Oxford University Press.

Wyss, Michel. 2019. 'Palästina war und wird für immer islamisch sein!'-Israelfeindschaft und Antisemitismus bei Hamas, Al-Qaida und dem Islamischen Staat. In Antisemitismus in der Gegenwartsgesellschaft. Edited by Nikolaus Hagen and Tobias Neuburger. Innsbruck: Innsbruck University Press, forthcoming.

(C) 2019 by the author. Licensee MDPI, Basel, Switzerland. This article is an open access article distributed under the terms and conditions of the Creative Commons Attribution (CC BY) license (http://creativecommons.org/licenses/by/4.0/). 